\title{
Liquid biopsies for colorectal cancer: a narrative review of ongoing clinical trials and the current use of this technology at a comprehensive cancer center
}

\author{
Sacha P. Broccard ${ }^{1} \wedge$, Ali Abbaszadeh Kasbi ${ }^{1}$, Sanjay P. Bagaria ${ }^{1}$, Jeremy Jones ${ }^{2}$, Mira Shoudry $^{1}$, \\ Emmanuel M. Gabriel ${ }^{1}$ \\ ${ }^{1}$ Section of Surgical Oncology, Mayo Clinic, Jacksonville, FL, USA; ${ }^{2}$ Division of Oncology, Mayo Clinic, Jacksonville, FL, USA \\ Contributions: (I) Conception and design: SP Broccard, SP Bagaria, EM Gabriel; (II) Administrative support: SP Broccard, A Abbaszadeh Kasbi, \\ EM Gabriel; (III) Provision of study materials or patients: SP Broccard, SP Bagaria, A Abbaszadeh Kasbi, EM Gabriel; (IV) Collection and assembly \\ of data: SP Broccard, A Abbaszadeh Kasbi; (V) Data analysis and interpretation: SP Broccard, A Abbaszadeh Kasbi, EM Gabriel; (VI) Manuscript \\ writing: All authors; (VII) Final approval of manuscript: All authors. \\ Correspondence to: Sacha P. Broccard, MD; Emmanuel M. Gabriel, MD, PhD. Section of Surgical Oncology, Mayo Clinic, Jacksonville, FL 32224, USA. \\ Email: Broccard.Sacha@mayo.edu; Gabriel.Emmanuel@mayo.edu.
}

\begin{abstract}
Objective: In this review, we summarize ongoing clinical trials involving liquid biopsies (LB) for colorectal cancer (CRC), outlining the current landscape and the future implementation of this technology. We also describe the current use of LB in CRC treatment at our institution, the Mayo Clinic Enterprise.
\end{abstract}

Background: The use of LB in CRC treatment merits close attention. Their role is being evaluated in the screening, non-intervention, intervention, and surveillance settings through many active trials. This, coupled with the technique's rapid integration into clinical practice, creates constant evolution of care.

Methods: Review of ClinicalTrials.gov was performed identifying relevant and active trials involving LB for CRC. "Colorectal cancer" plus other terms including "liquid biopsies" and "ctDNA" were used as search terms, identifying 35 active trials.

Conclusions: LB use for the CRC is actively being investigated and requires close attention. Based on current evidence, Mayo Clinic Enterprise currently uses LB in the non-interventional, interventional and surveillance setting, but not for screening. Results of these trials may further establish the use of LB in the management of CRC.

Keywords: Liquid biopsy; colorectal cancer (CRC); clinical trial

Submitted Aug 04, 2021. Accepted for publication Nov 30, 2021.

doi: $10.21037 /$ jgo-21-470

View this article at: https://dx.doi.org/10.21037/jgo-21-470

\section{Introduction}

In 1948, Mandel and Metais first described obtaining circulating tumor DNA (ctDNA) from the bloodstream (1). As the technology matured, ctDNA was found to correlate with disease burden. Later, following advances in prenatal testing, the use of tumor specific ctDNA to identify gene mutations was developed. Targeted and untargeted approaches allow for the identification of individual genes or genome wide analysis, respectively (2). Next-generation

\footnotetext{
^ ORCID: 0000-0002-1696-6542.
} 
based high-throughput sequencing substantially reduced costs. At the same time, it generates large amounts of data with unspecified clinical utility. Machine learning and artificial intelligence offer an apparent solution because they have the capacity to analyze a large volume of individual data points provided by a single liquid biopsy (3). As ctDNA allows for mutational analysis in a minimally invasive way, without the need for resection or excision, it can be used to improve early diagnosis, prognosis, therapy monitoring (4). Tumor-uninformed testing includes NGS with probe set to evaluate the standard set of genes and report out variants. Additional sensitivity can be achieved by using methylation signatures $(5,6)$. Conversely, tumor-informed testing involves sequencing to identify specific mutations present in an individual tumor and then testing only for specified previously identified mutations. This affords the ability to identify rare mutations per million base pairs, however new mutations are more difficult to identify compared to tumornon informed testing (6).

With the rise of and continued move towards personalized medicine, the thirst for the implementation and routine use of these technologies in the clinical setting continues to grow. Data proving benefit of obtaining realtime tumor-specific information throughout the colorectal cancer (CRC) treatment process is not yet available. Therefore, the frequency with which ctDNA meaningfully impacts care remains largely unproven $(7,8)$. Although, up to now, no test based on liquid biopsy is approved for monitoring the response during treatment, several studies have been demonstrated the promising role of ctDNA in monitoring of treatment response, leading to early detection of progressive disease. Accordingly, ctDNA can improve both specificity and sensitivity of monitoring response. Most studies assessing this role have focused on CRC, melanoma, breast cancer, and non-small cell lung cancer (9-12).

As there are different mechanisms by which different tumors release various amount of ctDNA into the blood, most studies have been focused on patients with metastatic cancers (13). Understanding the strengths and limitations of this technology, as well as how and when to implement it, is currently being examined in multiple ongoing trials. In this review, we focus specifically on the active clinical trials that show promise to continue pushing the forefront of ctDNA and its utility in the management of CRC. We divide the intended and desired clinical utility of ctDNA into four settings: screening, non-interventional (prognostication), interventional (treatment decisionmaking), and surveillance. Each of these settings can be further divided into multiple independent clinical applications. In the screening setting, ctDNA is under investigation as a tool for early detection of colorectal malignant and precancerous lesions. ctDNA is accepted as a method of detecting persistent micro-metastatic disease following definitive treatment, referred to as minimal residual disease (MRD) in some disease states but remains unproven in others. In the non-interventional setting, MRD shows promise as a tool for prognostication, while ctDNA allows identification of mutated genes such as KRAS, NRAS, $B R A F, A P C$, when tumor tissue is not available. To evaluate MRD, ctDNA can be obtained from both plasma or urine. However, detecting ctDNA in urine less sensitive and less specific than plasma because of significantly lower levels. Thus, ctDNA may detect the micro metastasis or MRD earlier than image-based diagnosis. In the interventional setting, MRD is being evaluated to guide the use of adjuvant chemotherapy (ACT). Additionally, during active treatment ctDNA may aid in detecting therapy resistance, adjusting treatment and de-escalation. In the surveillance setting, ctDNA is being evaluated as a method of detecting recurrence. Taken together, this technique has the potential to impact care throughout the diagnosis and treatment of CRC $(11,12,14,15)$. The purpose of this review is to outline the currently ongoing active clinical trials investigating liquid biopsies (LB) for CRC. We present the following article in accordance with the Narrative Review reporting checklist (available at https://jgo.amegroups.com/article/ view/10.21037/jgo-21-470/rc).

\section{Methods}

For the identification of trials that would be discussed in this review, ClinicalTrials.gov was used. "Colorectal cancer" was used as the search term under "Condition or disease" "liquid biopsies" and "ctDNA" were used as the search terms for "Other terms". This identified 35 trials; 7 trials were excluded either due to premature termination secondary to inadequate accrual, uncertain status, or lack of relevance with current review. This resulted in 28 trials meeting criteria for inclusion.

\section{Results}

\section{Current clinical trials of $L B$ in $C R C$}

\section{LB for screening}

The following trials in Table 1 explore the use of ctDNA 
Table 1 Active trails regarding LB for screening

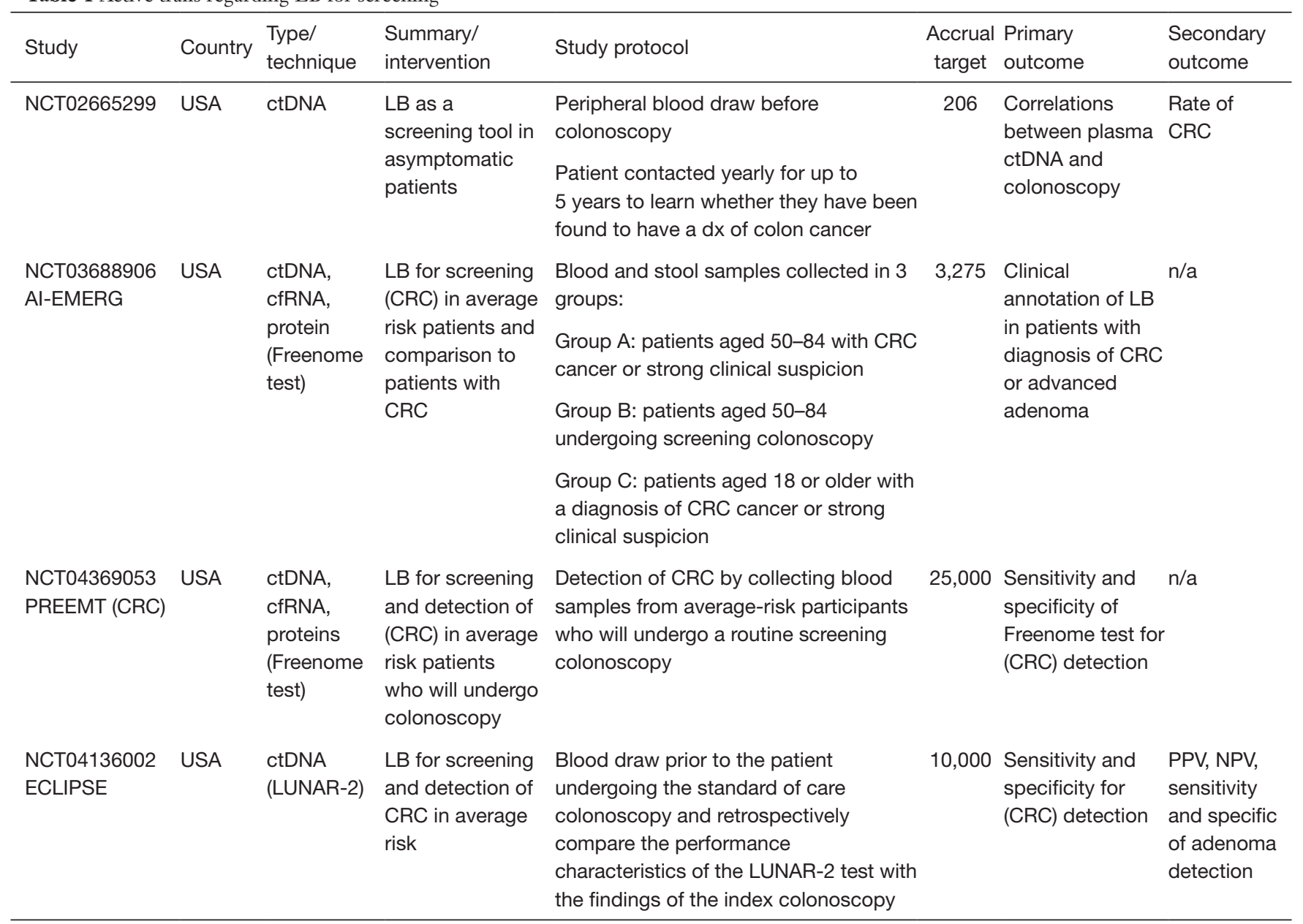

LB, liquid biopsies; ctDNA, circulating tumor DNA; CRC, colorectal cancer.

for CRC screening. With recent studies demonstrating promising levels of sensitivity and specificity for detecting cancerous lesions, large multisite population-based trials are currently enrolling patients. One major limitation is the inability to achieve adequate sensitivity for detecting precancerous lesions such as small adenomas. The benefit of LB for screening will likely be in high risk populations and in combination with other tools to calculate risk and determine timing for endoscopic evaluation. While LB will play a role as an addition to standard screening practices, it will likely not serve as a replacement.

\section{Non-interventional LB (i.e., prognostication)}

Eleven trials (Table 2) evaluate the pathophysiology and biochemical characteristics of ctDNA throughout CRC treatment: including surgery, chemotherapy, radiation therapy and immunotherapy. Understanding how and when to collect samples, and correlating them to different stages in treatment allows determination of their prognostic value. These trials highlight the importance of establishing institutional protocols for collecting and storing specimens as well as for multi-institutional data comparison.

\section{Interventional LB}

Ten trials (Table 3) are aimed at identifying LB as tool for guiding therapy and for triggering modifications in treatment. The growing understanding of MRD and its implications position LB to make a significant impact on adjuvant therapy. Patients receiving care at Mayo Clinic benefit from information gained with post-resection LB. Interventional LB trials constitute a growing proportion of trials, a trend that will continue as non-interventional LB 
Table 2 Active trails regarding non-interventional LB

\begin{tabular}{|c|c|c|c|c|c|c|c|}
\hline Study & Country & $\begin{array}{l}\text { Type/ } \\
\text { technique }\end{array}$ & Summary/intervention & Study protocol & $\begin{array}{l}\text { Accrual } \\
\text { target }\end{array}$ & Primary outcome & $\begin{array}{l}\text { Secondary } \\
\text { outcome }\end{array}$ \\
\hline NCT03776591 & Norway & ctDNA & $\begin{array}{l}\text { Compare surgical } \\
\text { technique of open } \\
\text { D33 vs. Lap CME for } \\
\text { right sided CRC }\end{array}$ & $\begin{array}{l}\text { Patients } \leq 85 \text { years with tumor } \\
\text { localized in the right colon } \\
\text { included. Blood samples } \\
\text { for analysis of ctDNA/CTCs } \\
\text { collected preoperatively, 3-10th } \\
\text { postoperative day, at } 3 \text { months, } \\
\text { and at each check the next five } \\
\text { years at six months intervals. } \\
\text { Sample times correlated to } \\
\text { surveillance CEA and CT }\end{array}$ & 218 & Complications & $\begin{array}{l}\text { Prognostic } \\
\text { significance } \\
\text { of ctDNA }\end{array}$ \\
\hline $\begin{array}{l}\text { NCT04726800 } \\
\text { CITCCA }\end{array}$ & $\begin{array}{l}\text { Norway, } \\
\text { Sweden }\end{array}$ & ctDNA & $\begin{array}{l}\text { Feasibility of profiling } \\
\text { ctDNA in stage I-III } \\
\text { CRC }\end{array}$ & $\begin{array}{l}\text { Blood draw before surgery } \\
\text { (baseline), after surgery at } \\
4-6 \text { weeks, 3-, 6-, 12- and } \\
24 \text { months postoperatively to } \\
\text { measure ctDNA in plasma }\end{array}$ & 300 & $\begin{array}{l}\text { Rate of post-op } \\
\text { ctDNA+, rate of } \\
\text { ctDNA+ conversion } \\
\text { to ctDNA-negative } \\
\text { following surgery }\end{array}$ & $\mathrm{n} / \mathrm{a}$ \\
\hline $\begin{array}{l}\text { NCT04108481 } \\
\text { iRE-C }\end{array}$ & USA & ctDNA & $\begin{array}{l}\text { Feasibility and } \\
\text { safety of Y90 with } \\
\text { immunotherapy in } \\
\text { MCRC MSS }\end{array}$ & $\begin{array}{l}\text { Analyze changes in the } \\
\text { expression profile and in levels } \\
\text { of ctDNA in blood pre- and } \\
\text { post- treatment with Y90- } \\
\text { radioembolization }\end{array}$ & 18 & $\begin{array}{l}\text { Maximum tolerated } \\
\text { Y90 dose in } \\
\text { combination with } \\
\text { immunotherapy }\end{array}$ & $\begin{array}{l}\text { ctDNA } \\
\text { levels pre- } \\
\text { and post- } \\
\text { treatment, } \\
\text { adverse } \\
\text { events, } \\
\text { response rate }\end{array}$ \\
\hline $\begin{array}{l}\text { NCT03284684 } \\
\text { Periop ctDNA }\end{array}$ & France & ctDNA & $\begin{array}{l}\text { Determine kinetics of } \\
\text { perioperative ctDNA } \\
\text { testing in CRC, breast } \\
\text { and prostate }\end{array}$ & $\begin{array}{l}\text { Analyze the kinetics of } \\
\text { perioperative circulating DNA } \\
\text { in breast, prostate, and colon } \\
\text { cancer }\end{array}$ & 30 & $\begin{array}{l}\text { ctDNA concentration, } \\
\text { ctDNA integrity, } \\
\text { ctDNA proportion }\end{array}$ & $\begin{array}{l}\text { Plasma } \\
\text { concentration } \\
\text { of } K D R A \text {, } \\
A C T B\end{array}$ \\
\hline NCT04491929 & Denmark & ctDNA & $\begin{array}{l}\text { Describe tumor } \\
\text { specific mutations } \\
\text { using ctDNA in } \\
\text { patients undergoing } \\
\text { Y90 for refractory } \\
\text { MCRC }\end{array}$ & $\begin{array}{l}\text { Total cell free DNA level will be } \\
\text { quantified in all samples. The } \\
\text { samples will be analyzed for } \\
\text { tumor specific mutations such } \\
\text { as the KRAS, BRAF and NRAS } \\
\text { oncogenes }\end{array}$ & 30 & Feasibility & $\begin{array}{l}\text { Response } \\
\text { rate, PFS, OS }\end{array}$ \\
\hline $\begin{array}{l}\text { NCT03841799 } \\
\text { COLON-IM }\end{array}$ & France & ctDNA & $\begin{array}{l}\text { Describe local tissue } \\
\text { microenvironment of } \\
\text { patients with CRC }\end{array}$ & $\begin{array}{l}\text { Blood and stool samples } \\
\text { at surgery, at month } 3 \text { post } \\
\text { surgery and at month } 6 \text { post } \\
\text { surgery }\end{array}$ & 80 & $\begin{array}{l}\text { Characterize local } \\
\text { microenvironment }\end{array}$ & $\begin{array}{l}\text { Describe } \\
\text { ctDNA, } \\
\text { lymphocyte } \\
\text { infiltrate, } \\
\text { cytokine } \\
\text { environment }\end{array}$ \\
\hline
\end{tabular}

Table 2 (continued) 
Table 2 (continued)

\begin{tabular}{|c|c|c|c|c|c|c|c|}
\hline Study & Country & $\begin{array}{l}\text { Type/ } \\
\text { technique }\end{array}$ & Summary/intervention & Study protocol & $\begin{array}{c}\text { Accrual } \\
\text { target }\end{array}$ & Primary outcome & $\begin{array}{l}\text { Secondary } \\
\text { outcome }\end{array}$ \\
\hline $\begin{array}{l}\text { NCT03975491 } \\
\text { EХACT }\end{array}$ & USA & ctDNA & $\begin{array}{l}\text { Evaluate relationship } \\
\text { between exercise } \\
\text { and recurrence in } \\
\text { post treatment CRC }\end{array}$ & $\begin{array}{l}\text { Exercise intervention consists } \\
\text { of moderate-intensity ( } 50-70 \% \\
\text { age-predicted maximum } \\
\text { heart rate) treadmill walking. } \\
\text { Examine the effect of } 12 \text { week } \\
\text { aerobic exercise on systemic } \\
\text { inflammation, CRP, IL-6, insulin } \\
\text { resistance quantified using an } \\
\text { oral glucose tolerance test, and } \\
\text { ctDNA. }\end{array}$ & 60 & Levels of CRP, IL-6 & $\begin{array}{l}\text { Proportion } \\
\text { of ctDNA, } \\
\text { TNF, insulin } \\
\text { resistance }\end{array}$ \\
\hline $\begin{array}{l}\text { NCT03702309 } \\
\text { LIBERATE }\end{array}$ & Canada & $\begin{array}{l}\text { ctDNA, } \\
\text { cfRNA }\end{array}$ & Develop LB protocol & $\begin{array}{l}\text { Peripheral blood samples } \\
\text { collected serially for DNA } \\
\text { extraction for } 5 \text { years. }\end{array}$ & 2,500 & $\begin{array}{l}\text { Collection and } \\
\text { annotation of } \\
\text { biospecimens }\end{array}$ & $\mathrm{n} / \mathrm{a}$ \\
\hline
\end{tabular}

LB, liquid biopsies; ctDNA, circulating tumor DNA; CRC, colorectal cancer; SEMS, self-expanding metal stent; MRD, minimal residual disease; CAPE, capecitabine.

trials increase our understanding of the specific relationships between malignancy and ctDNA.

\section{LB for surveillance}

These four trials (Table 4) depict a future role of LB in the setting of surveillance and early identification of recurrence or relapse. The consistent use over the last half century of carcinoembryonic antigen (CEA) and the acknowledged limitations of this blood test exemplify the persistent interest in blood tests with the ability identify disease prior to radiologic visualization. Tumor informed tests, using patient/tumor specific sequencing, currently play a role in surveillance at Mayo Clinic and other institutions.

\section{The current Mayo Clinic practice (16)}

As there are limited publications on the actual clinical use, liquid biopsy-based technologies are far from reaching their full potential. Centers across North America, including our own, have begun integrating ctDNA to clinical practice to aid in the care of patients with CRCs. We report our institutional practice with LB as it pertains to the screening, non-interventional (prognostication), interventional (treatment decision-making), and surveillance settings. Our current standards of practice are based on interpretation of published (not ongoing) studies and are not intended to be institutional evidence-based recommendations (16).

* In the screening setting (Table 1), Mayo Clinic does not use LB as part of routine care.

* In the non-interventional setting (Table 2), LB is performed for patients with stage IV disease. This has potential benefits, including establishment of baseline ctDNA characteristics that may be compared to levels following treatment, correlation of ctDNA with the primary tumor characteristics, and obtaining material for analysis if tissue biopsy is not feasible.

* In the interventional setting (Table 3), LB-guided therapy alteration is occurring at Mayo Clinic.

* For patients with stage IV disease who are receiving systemic treatment, $L B$ is used when 
Table 3 Active trials regarding interventional LB

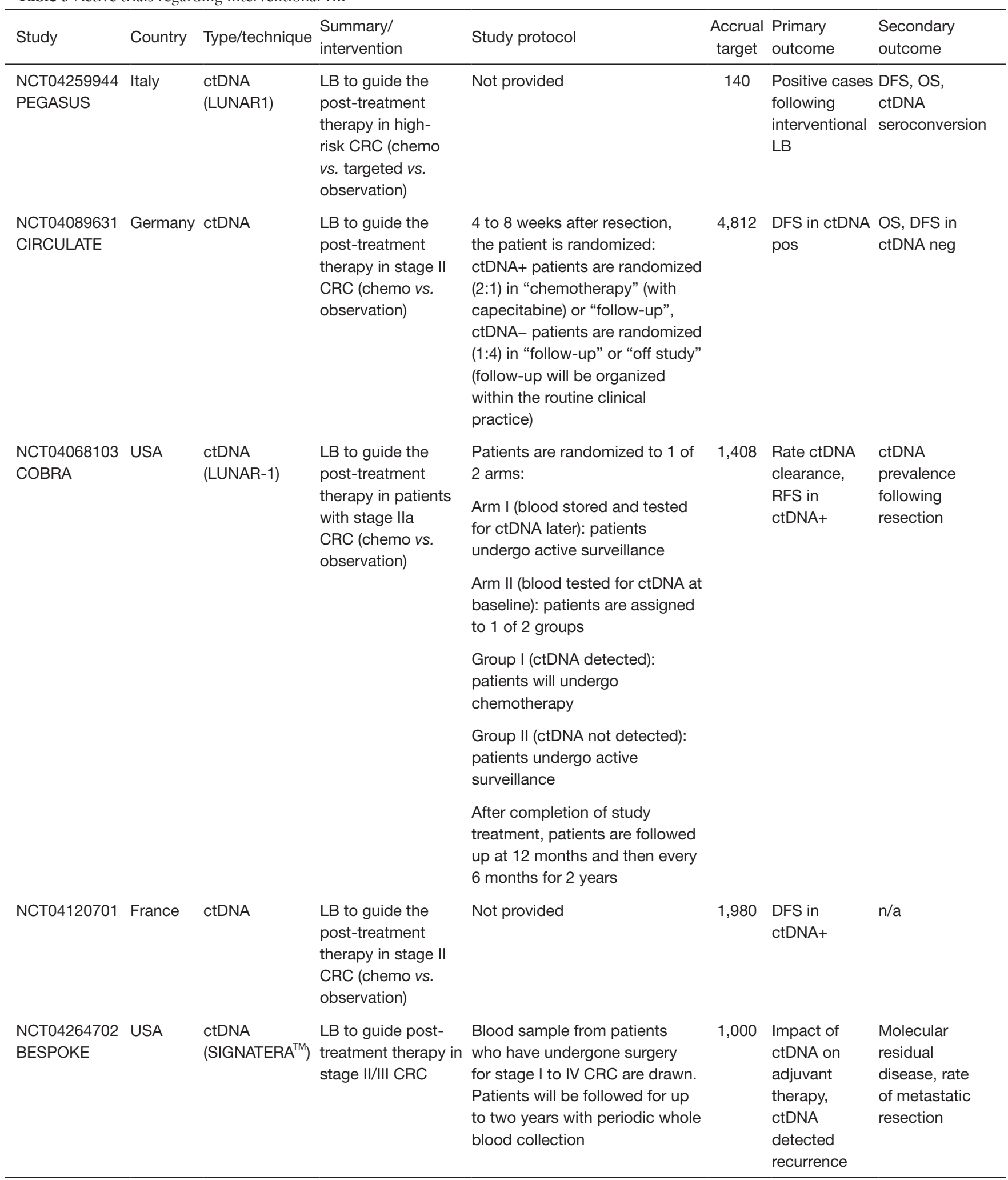

Table 3 (continued) 
Table 3 (continued)

\begin{tabular}{|c|c|c|c|c|c|c|c|}
\hline Study & Country & Type/technique & $\begin{array}{l}\text { Summary/ } \\
\text { intervention }\end{array}$ & Study protocol & $\begin{array}{l}\text { Accrual } \\
\text { target }\end{array}$ & $\begin{array}{l}\text { Primary } \\
\text { outcome }\end{array}$ & $\begin{array}{l}\text { Secondary } \\
\text { outcome }\end{array}$ \\
\hline NCT03803553 & USA & $\begin{array}{l}\text { CtDNA } \\
\text { (LUNAR-1) }\end{array}$ & $\begin{array}{l}\text { LB to guide post- } \\
\text { treatment therapy in } \\
\text { MCRC (chemo vs. } \\
\text { targeted vs. immune } \\
\text { vs. observation) }\end{array}$ & $\begin{array}{l}\text { Patients with stage III CRC } \\
\text { following resection assigned into } \\
1 \text { of } 3 \text { groups based on ctDNA } \\
\text { results: } \\
\text { ctDNA+: FOLFIRI } \\
\text { ctDNA+: active surveillance } \\
\text { ctDNA-: active surveillance }\end{array}$ & 500 & $\begin{array}{l}\text { DFS for } \\
\text { ctDNA+ } \\
\text { receiving } \\
\text { additional } \\
\text { treatment } \\
\text { compared to } \\
\text { ctDNA+ who } \\
\text { are observed, } \\
\text { ctDNA } \\
\text { clearance rate }\end{array}$ & OS, DFS \\
\hline $\begin{array}{l}\text { NCT02997241 } \\
\text { CCTDRP }\end{array}$ & China & ctDNA & $\begin{array}{l}\text { Determine } \\
\text { relationship } \\
\text { between change in } \\
\text { gene copies and } \\
\text { recurrence }\end{array}$ & $\begin{array}{l}\text { Phase I component: predict } \\
\text { recurrence through Oncocare } \\
\text { Phase II component: patients } \\
\text { placed into four groups on the } \\
\text { basis of genetic risk judged } \\
\text { by Oncocare }{ }^{\mathrm{TM}} \text { and clinical } \\
\text { risk judged by clinical routine } \\
\text { method }\end{array}$ & 500 & $\begin{array}{l}\text { Rate of } \\
\text { treatment of } \\
\text { chemo based } \\
\text { on standard } \\
\text { of care vs. } \\
\text { with ctDNA }\end{array}$ & \\
\hline NCT04775862 & $\begin{array}{l}\text { Saudi } \\
\text { Arabia }\end{array}$ & ctDNA & $\begin{array}{l}\text { LB to evaluate } \\
\text { RAS status and } \\
\text { guide rechallenge } \\
\text { with anti-EGFR in } \\
\text { advanced CRC }\end{array}$ & $\begin{array}{l}R A S \text { wild type and left sided } \\
\text { primary disease receive } \\
\text { standard chemotherapy with } \\
\text { an anti EGFR mAb. Upon } \\
\text { progression of disease, second } \\
\text { line systemic chemotherapy } \\
\pm \text { anti-VEGF antibody will be } \\
\text { given as per standard of care. } \\
\text { With progression, patients will } \\
\text { be enrolled into the study as per } \\
\text { inclusion criteria, and a cfDNA } \\
\text { blood test will be drawn, and } \\
R A S \text { status will be examined. } \\
\text { If } R A S \text { is wildtype, then the } \\
\text { investigator will decide whether } \\
\text { to re-challenge with an anti } \\
\text { EGFR antibody, or give standard } \\
\text { of care third line chemotherapy }\end{array}$ & (1) & $\begin{array}{l}\text { Response } \\
\text { rate, PFS }\end{array}$ & $\begin{array}{l}\text { Rate of RAS } \\
\text { wt after } \\
\text { progressions } \\
\text { using ctDNA }\end{array}$ \\
\hline NCT03436563 & USA & ctDNA & $\begin{array}{l}\text { Evaluate } \\
\text { immunotherapy for } \\
\text { MSI-H unresectable } \\
\text { MCRC and ctDNA+ } \\
\text { patients }\end{array}$ & $\begin{array}{l}\text { Patients receive M7824 IV over } \\
1 \text { hour on days } 1 \text { and } 15 . \text { Cycles } \\
\text { repeat every } 28 \text { days in the } \\
\text { absence of disease progression } \\
\text { or unacceptable toxicity or } \\
\text { for six doses in patients with } \\
\text { detectable ctDNA following } \\
\text { resection of all known liver } \\
\text { metastases }\end{array}$ & 74 & $\begin{array}{l}\text { Response } \\
\text { rate, } \\
\text { clearance of } \\
\text { ctDNA }\end{array}$ & $\begin{array}{l}\text { PFS, OS, DFS, } \\
\text { adverse events }\end{array}$ \\
\hline
\end{tabular}

Table 3 (continued) 
Table 3 (continued)

\begin{tabular}{|c|c|c|c|c|c|c|c|}
\hline Study & Country & Type/technique & $\begin{array}{l}\text { Summary/ } \\
\text { intervention }\end{array}$ & Study protocol & $\begin{array}{l}\text { Accrual } \\
\text { target }\end{array}$ & $\begin{array}{l}\text { Primary } \\
\text { outcome }\end{array}$ & $\begin{array}{l}\text { Secondary } \\
\text { outcome }\end{array}$ \\
\hline $\begin{array}{l}\text { NCT03765736 } \\
\text { COLOMATE }\end{array}$ & USA & ctDNA & $\begin{array}{l}\text { LB to identify } \\
\text { genetic mutations } \\
\text { in MCRC or } \\
\text { unresectable CRC }\end{array}$ & $\begin{array}{l}\text { Screens patients with colon } \\
\text { or rectal cancer that has } \\
\text { spread to other places in the } \\
\text { body (metastatic) or cannot } \\
\text { be removed by surgery } \\
\text { (unresectable) for genetic } \\
\text { mutations via blood samples } \\
\text { for recommendation to a } \\
\text { molecularly assigned therapy }\end{array}$ & 500 & $\begin{array}{l}\text { Proportion of } \\
\text { patients with } \\
\text { actionable } \\
\text { genomic } \\
\text { profile }\end{array}$ & $\mathrm{n} / \mathrm{a}$ \\
\hline NCT04670588 & USA & ctDNA & $\begin{array}{l}\text { Determine the } \\
\text { feasibility of } \\
\text { tumor response } \\
\text { assessment by } \\
\text { ctDNA in patients } \\
\text { with locally } \\
\text { advanced rectal } \\
\text { cancer undergoing } \\
\text { total neoadjuvant } \\
\text { therapy }\end{array}$ & $\begin{array}{l}\text { Peripheral blood sample } \\
\text { obtained } 4 \text { weeks before } \\
\text { neoadjuvant therapy. For patients } \\
\text { with } 16 \text { and } 8 \text { week therapy } \\
\text { respectively, } 3 \text { and } 2 \text { blood } \\
\text { samples for ctDNA are obtained. } \\
\text { Tumor response rate assessed } \\
\text { by ctDNA will be compared with } \\
\text { the response rate assessed by } \\
\text { the standard method to explore } \\
\text { if a significant correlation exists } \\
\text { between these two response } \\
\text { assessment methods }\end{array}$ & (1) & $\begin{array}{l}\text { Mean serum } \\
\text { ctDNA } \\
\text { concentration }\end{array}$ & $\begin{array}{l}\text { Response } \\
\text { based on } \\
\text { serum ctDNA } \\
\text { level, and } \\
\text { standard } \\
\text { clinical } \\
\text { assessments }\end{array}$ \\
\hline
\end{tabular}

LB, liquid biopsies; ctDNA, circulating tumor DNA; CRC, colorectal cancer.

disease resistance is identified radiologically and there is concern for mutation. For example, LB potentially guides discontinuation of an $E G F R$ inhibitor when a new $K R A S / R A S$ mutation is identified on ctDNA.

* Post-surgical LB to evaluate MRD following resection is selectively used to identify patients who have a higher risk of recurrence. This information can occasionally help guide adjuvant therapy discussions; however, we would caution against its routine use in clinical practice until prospective trials show a benefit from early detection and treatment.

In our view, ctDNA should not be used as a decision point for de-escalation of ACT until fully studied in prospective trials given the relatively poor sensitivities for these tests (generally less than $50 \%$ sensitive for single time point). LB is provided by independent companies (e.g., Natera Inc., San Carlos, CA, USA) and is selectively used for surveillance with sequential LBs at progressive intervals in combination with traditional biochemical tests (i.e., serum CEA levels). The tests used are primarily tumor non-informed (i.e., Guardant360) at initiation and during treatment while tumor informed (i.e., Natera) are used for detecting recurrence (16).

\section{Discussion}

These active LB trials reveal the broad investigation of the many possible uses of LB as well as its pathophysiology. By breaking down the setting of LB use in current ongoing clinical trials, we can better understand the focus and desired integration of this technology. Of the 29 clinical trials, four are evaluating LBs in the screening setting, eleven are looking at non-interventional LB use, ten are focused on interventional $\mathrm{LB}$, and four in the surveillance setting. Multiple recent in-depth reviews (2,16-20). have extensively outlined the potential impacts of LBs on clinical practice and the theoretical benefits of early detection, improved prognostication, ACT escalation, ACT deescalation, LB guided ACT adjustments, and earlier identification of recurrence. Moreover, it can be used as a 
Table 4 Active trails regarding LB for surveillance

\begin{tabular}{|c|c|c|c|c|c|c|c|}
\hline Study & Country & $\begin{array}{l}\text { Type/ } \\
\text { technique }\end{array}$ & Summary/intervention & Study protocol & $\begin{array}{l}\text { Accrual } \\
\text { target }\end{array}$ & Primary outcome & $\begin{array}{l}\text { Secondary } \\
\text { outcome }\end{array}$ \\
\hline $\begin{array}{l}\text { NCT03883802 } \\
\text { NeoFox }\end{array}$ & Spain & ctDNA & $\begin{array}{l}\text { Tolerability and effect } \\
\text { of Foxy- } 5 \text { in neo- } \\
\text { adjuvant setting for } \\
\text { CRC }\end{array}$ & $\begin{array}{l}\text { The level of ctDNA in plasma as a } \\
\text { surrogate for disease recurrence } \\
\text { in patients with Wnt-5a low colon } \\
\text { cancer treated with Foxy- } 5 \text {. }\end{array}$ & 100 & $\begin{array}{l}\text { Adverse events, } \\
\text { ctDNA as marker } \\
\text { for disease free } \\
\text { period }\end{array}$ & $\begin{array}{l}\text { OS, DFS, } \\
\text { RFI }\end{array}$ \\
\hline \multirow{2}{*}{$\begin{array}{l}\text { NCT04084249 } \\
\text { IMPROVE-IT2 }\end{array}$} & \multirow{2}{*}{ Denmark } & \multirow{2}{*}{ ctDNA } & \multirow{2}{*}{$\begin{array}{l}\text { LB to guided post- } \\
\text { treatment surveillance }\end{array}$} & $\begin{array}{l}\text { Experimental: ctDNA guided } \\
\text { surveillance }\end{array}$ & \multirow{2}{*}{254} & \multirow{2}{*}{$\begin{array}{l}\text { Fraction of patient } \\
\text { with recurrence } \\
\text { receiving curative } \\
\text { intent treatment }\end{array}$} & \multirow{2}{*}{$\begin{array}{l}\text { OS, time } \\
\text { to clinical } \\
\text { recurrence }\end{array}$} \\
\hline & & & & $\begin{array}{l}\text { No intervention: standard Danish } \\
\text { follow-up program }\end{array}$ & & & \\
\hline \multirow[t]{3}{*}{$\begin{array}{l}\text { NCT04046445 } \\
\text { KISIMA-01 }\end{array}$} & \multirow[t]{3}{*}{ USA } & \multirow[t]{3}{*}{ ctDNA } & \multirow[t]{3}{*}{$\begin{array}{l}\text { Phase Ib for ATP128 } \\
\text { alone or with BI } 754091 \\
\text { for stage IV CRC } \\
\text { MSS anti PD-1 non- } \\
\text { responders }\end{array}$} & $\begin{array}{l}\text { Patients with CRC stage IV } \\
\text { assigned in one of the following } \\
\text { groups: } \\
\text { Cohort 1a: } 6 \text { patients with stage } \\
\text { IV CRC }\end{array}$ & \multirow[t]{3}{*}{32} & \multirow[t]{3}{*}{$\begin{array}{l}\text { Safety and } \\
\text { tolerability }\end{array}$} & \multirow[t]{3}{*}{$\begin{array}{l}\text { Detect early } \\
\text { signal of } \\
\text { relapse by } \\
\text { ctDNA }\end{array}$} \\
\hline & & & & $\begin{array}{l}\text { Cohort } 2 \mathrm{~b}: 15 \text { patients with stage } \\
\text { IV MSS/MMRp with liver-limited } \\
\text { CRC }\end{array}$ & & & \\
\hline & & & & $\begin{array}{l}\text { Cohort 2c: } 19 \text { patients with } \\
\text { stage IV MSS/MMRp CRC with } \\
\text { progression }\end{array}$ & & & \\
\hline NCT03615170 & China & ctDNA & $\begin{array}{l}\text { Application of ctDNA } \\
\text { test in the diagnosis } \\
\text { and treatment of } \\
\text { patients with advanced } \\
\text { rectal cancer }\end{array}$ & Not provided & 200 & $\begin{array}{l}\text { Disease free } \\
\text { survival }\end{array}$ & $\mathrm{n} / \mathrm{a}$ \\
\hline
\end{tabular}

LB, liquid biopsies; ctDNA, circulating tumor DNA; CRC, colorectal cancer. 
reliable biomarker for treatment response monitoring (21). However, the standardization of protocols and assays across institutions, has not kept up with the strong desire to include ctDNA within clinical trials or clinical care.

The National Cancer Institute's recent publication and recommendation to address implementation barriers for the use of ctDNA in CRC merits attention (8). This NCI paper accepts ctDNA as a viable marker for MRD. For patients without tumor tissue available, recommendations state ctDNA provides reliable tumor material for analysis. They endorse next-generation sequencing-based multigene assays as the superior technique as opposed to the PCRbased assays. Noting the variability of the ctDNA assays and pre-analytical variables, the NCI stresses the importance of standardization of practices. Proactive collaboration in creating high-quality databases that allow for subsequent pooled analysis is essential for establishing clinical utility. Overall, the NCI task force simply recommends the continued evaluation of these technologies with emphasis on collaborative initiatives (8).

Though the current NCI recommendations do not entirely guide LB use, their conclusions for achieving cohesive and reproducible results are actionable. Certain settings for LB use, such as surveillance, have lower barriers for entrance into clinical practice $(22,23)$. There are a few active LB trials that are promising across each setting. In the screening setting, AL EMERGE Trial in CRC (NCT03688906) evaluated 3,275 asymptomatic patients. Dr. Putcha et al. (24) reported 94\% sensitivity and specificity rate in screening for stage I/II CRC. The follow-up trial, PREEMT CRC (NCT04369053) is actively recruiting patients with a goal of 25,000 . In the noninterventional LB setting, CITCCA (Scandinavia), is one of the larger trials with a goal of 300 patients evaluating perioperative ctDNA and its role in prognostication. In the interventional LB setting, the CIRCULATE trial out of Germany randomized 4,812 patients with stage II CRC with ctDNA+ to ACT or follow-up. In the surveillance setting, the IMPROVE-IT2 trial out of Denmark randomizes CRC patients to ctDNA surveillance or standard Danish followup. One of the more valuable trials that is directly in line with NCI recommendations comes from Canada. Though it is not immediately impactful, the LIBERATE trial aims to establish an institution wide LB protocol.

Reimbursement plays an important role in the clinical adoption of these technologies as the evidence regarding their utility unfolds. As the evidence continues to emerge, reimbursement will likely impact the clinical adoption of these technologies. The cost, though continually dropping, must be factored into decision-making as the potential for sequential LB in numerous cancers could significantly impact the cost of cancer care. A recent JNCCN review described the specifics of ctDNA reimbursement from Medicare and more than 200 commercial payers between 2015 and $2019(25,26)$. The variation in insurance policy structures, indications for testing, coverage by test type, and the documentation required for approval of testing creates an exceedingly confusing landscape for all parties involved. While ctDNA coverage has expanded from a previously near-exclusive use in NSCLC to pan-cancer use, its coverage remains significantly (27) limited. Solid tumor analysis for non-specified gene (i.e., Grardant360) was covered in 4 policies $(14 \%)$ of private payers and in 4 Medicare policies. Although sequential LB throughout treatment provides more accurate and more actionable data, most payers cover one-time tests for treatment selection. Only $11 \%$ of the few payers covering any LB testing, cover sequential ctDNA testing for disease and treatment monitoring (25-27).

\section{Conclusions}

The desire to implement and benefit from LB across CRC care continues to grow. Technological innovations, including next-generation sequencing and pooled algorithmic automated analysis, combined with sequential data extraction has led to highly sensitive and specific tests. The intended use of LB throughout the diagnosis, treatment, and surveillance of CRC is actively under investigation. There is broad acceptance that ctDNA can detect MRD and these technologies are selectively being integrated into practice. Mayo Clinic currently uses ctDNA to adjust treatment in stage IV disease, to identify the low-risk stage II patients that may benefit from ACT, and selectively for surveillance. However, the lack of standardization in LB protocols-preanalytical processing, storage, and analytical methods - has prevented acceptable cross study verification. Because of this, NCI recommendations are still broad-based and call for continued collaborative evaluation of LB use. The collaboration of national databases, such as BloodPAC in North America and the European Liquid Biopsy, will be key to further the safe, effective, and clinically useful implementation of LB technologies.

\section{Acknowledgments}

Funding: None. 


\section{Footnote}

Reporting Checklist: The authors have completed the Narrative Review reporting checklist. Available at https:// jgo.amegroups.com/article/view/10.21037/jgo-21-470/rc

Peer Review File: Available at https://jgo.amegroups.com/ article/view/10.21037/jgo-21-470/prf

Conflicts of Interest: All authors have completed the ICMJE uniform disclosure form (available at https://jgo.amegroups. com/article/view/10.21037/jgo-21-470/coif). The authors have no conflicts of interest to declare.

Ethical Statement: The authors are accountable for all aspects of the work in ensuring that questions related to the accuracy or integrity of any part of the work are appropriately investigated and resolved.

Open Access Statement: This is an Open Access article distributed in accordance with the Creative Commons Attribution-NonCommercial-NoDerivs 4.0 International License (CC BY-NC-ND 4.0), which permits the noncommercial replication and distribution of the article with the strict proviso that no changes or edits are made and the original work is properly cited (including links to both the formal publication through the relevant DOI and the license). See: https://creativecommons.org/licenses/by-nc-nd/4.0/.

\section{References}

1. Mandel P, Metais P. Nuclear Acids In Human Blood Plasma. C R Seances Soc Biol Fil 1948;142:241-3.

2. Alix-Panabières C, Pantel K. Liquid Biopsy: From Discovery to Clinical Application. Cancer Discov 2021;11:858-73.

3. Cario CL, Chen E, Leong L, et al. A machine learning approach to optimizing cell-free DNA sequencing panels: with an application to prostate cancer. BMC Cancer 2020;20:820.

4. Neumann MHD, Bender S, Krahn T, et al. ctDNA and CTCs in Liquid Biopsy - Current Status and Where We Need to Progress. Comput Struct Biotechnol J 2018;16:190-5.

5. Luo H, Zhao Q, Wei W, et al. Circulating tumor DNA methylation profiles enable early diagnosis, prognosis prediction, and screening for colorectal cancer. Sci Transl Med 2020;12:eaax7533.
6. Chen M, Zhao H. Next-generation sequencing in liquid biopsy: cancer screening and early detection. Hum Genomics 2019;13:34.

7. Zhang Q, Luo J, Wu S, et al. Prognostic and Predictive Impact of Circulating Tumor DNA in Patients with Advanced Cancers Treated with Immune Checkpoint Blockade. Cancer Discov 2020;10:1842-53.

8. Dasari A, Morris VK, Allegra CJ, et al. ctDNA applications and integration in colorectal cancer: an NCI Colon and Rectal-Anal Task Forces whitepaper. Nat Rev Clin Oncol 2020;17:757-70.

9. Boonstra PA, Wind TT, van Kruchten M, et al. Clinical utility of circulating tumor DNA as a response and followup marker in cancer therapy. Cancer Metastasis Rev 2020;39:999-1013.

10. Bratman SV, Yang SYC, Iafolla MAJ, et al. Personalized circulating tumor DNA analysis as a predictive biomarker in solid tumor patients treated with pembrolizumab. Nat Cancer 2020;1:873-81.

11. Wang Y, Yang L, Bao H, et al. Utility of ctDNA in predicting response to neoadjuvant chemoradiotherapy and prognosis assessment in locally advanced rectal cancer: A prospective cohort study. PLoS Med 2021;18:e1003741.

12. Li J, Jiang W, Wei J, et al. Patient specific circulating tumor DNA fingerprints to monitor treatment response across multiple tumors. J Transl Med 2020;18:293.

13. Speicher MR, Pantel K. Tumor signatures in the blood. Nat Biotechnol 2014;32:441-3.

14. Naidoo M, Gibbs P, Tie J. ctDNA and Adjuvant Therapy for Colorectal Cancer: Time to Re-Invent Our Treatment Paradigm. Cancers (Basel) 2021;13:346.

15. Pellini B, Pejovic N, Feng W, et al. ctDNA MRD Detection and Personalized Oncogenomic Analysis in Oligometastatic Colorectal Cancer From Plasma and Urine. JCO Precis Oncol 2021;5:ePO.

16. Gabriel E, Bagaria SP. Assessing the Impact of Circulating Tumor DNA (ctDNA) in Patients With Colorectal Cancer: Separating Fact From Fiction. Front Oncol 2018;8:297.

17. Chakrabarti S, Xie H, Urrutia R, et al. The Promise of Circulating Tumor DNA (ctDNA) in the Management of Early-Stage Colon Cancer: A Critical Review. Cancers (Basel) 2020;12:2808.

18. Ignatiadis $M$, Sledge GW, Jeffrey SS. Liquid biopsy enters the clinic - implementation issues and future challenges. Nat Rev Clin Oncol 2021;18:297-312.

19. Osumi H, Shinozaki E, Yamaguchi K, et al. Clinical utility of circulating tumor DNA for colorectal cancer. Cancer 
Sci 2019;110:1148-55.

20. Marcuello M, Vymetalkova V, Neves RPL, et al. Circulating biomarkers for early detection and clinical management of colorectal cancer. Mol Aspects Med 2019;69:107-22.

21. Henriksen TV, Tarazona N, Reinert T, et al. Circulating tumor DNA analysis for assessment of recurrence risk, benefit of adjuvant therapy, and early relapse detection after treatment in colorectal cancer patients. J Clin Oncol 2021;39:11.

22. Tie J, Cohen JD, Wang Y, et al. Circulating Tumor DNA Analyses as Markers of Recurrence Risk and Benefit of Adjuvant Therapy for Stage III Colon Cancer. JAMA Oncol 2019;5:1710-7.

23. Tie J, Wang Y, Tomasetti C, et al. Circulating tumor DNA analysis detects minimal residual disease and predicts recurrence in patients with stage II colon cancer. Sci Transl
Med 2016;8:346ra92.

24. AI-EMERGE: Development and Validation of a Multianalyte, Blood-based Colorectal Cancer Screening Test 2021. Available online: https://clinicaltrials.gov/ct2/show/ NCT03688906

25. Douglas MP, Gray SW, Phillips KA. Private Payer and Medicare Coverage for Circulating Tumor DNA Testing: A Historical Analysis of Coverage Policies From 2015 to 2019. J Natl Compr Canc Netw 2020;18:866-72.

26. Felgner S, Ex P, Henschke C. Physicians' Decision Making on Adoption of New Technologies and Role of Coverage with Evidence Development: A Qualitative Study. Value Health 2018;21:1069-76.

27. IJzerman MJ, de Boer J, Azad A, et al. Towards Routine Implementation of Liquid Biopsies in Cancer Management: It Is Always Too Early, until Suddenly It Is Too Late. Diagnostics (Basel) 2021;11:103.
Cite this article as: Broccard SP, Abbaszadeh Kasbi A, Bagaria SP, Jones J, Shoudry M, Gabriel EM. Liquid biopsies for colorectal cancer: a narrative review of ongoing clinical trials and the current use of this technology at a comprehensive cancer center. J Gastrointest Oncol 2022;13(1):438-449. doi: 10.21037/jgo-21-470 